\title{
BIODEGRADATION OF MANGO SEED STARCH FILMS IN SOIL
}

\author{
NUR'Aishah AHMAd ShaHrim", NORSHAHIDa SARIFUdDIN, \\ Ahmad Zahirani Ahmad Azhar and Hafizah Hanim Mohd ZaKi \\ Department of Manufacturing and Materials Engineering, Kulliyyah of Engineering, \\ International Islamic University Malaysia, \\ Jalan Gombak, 53100 Kuala Lumpur, Malaysia
}

*Corresponding author: nuraishahahmadshahrim@gmail.com

(Received: $21^{\text {st }}$ September 2020; Accepted: 13 th October 2021; Published on-line: $4^{\text {th }}$ January 2022)

\begin{abstract}
The typical petroleum-based plastics have triggered environmental problems. For this purpose, biodegradable polymers such as starch are often used to manufacture biodegradable plastics. At present, the efforts are underway to extract starch as a promising biopolymer from mango seeds and subsequently to produce a biodegradable starch film to be used as plastic packaging. As such, in this work, glycerolplasticized mango starch films were prepared using a solution casting process, using different amounts of citric acid as a cross-linking agent. The blend ratio of starch to glycerol was set at 3:5 wt. each, while the amount of citric acid ranged from 0 to $10 \mathrm{wt} . \%$. Then, the casted films underwent 21 days of soil burial testing in the natural environment to determine their biodegradability behavior. The soil burial test is one of the common methods chosen to assess the biodegradability of polymers. The idea is that, by burying samples in the soil for a fixed time, samples are exposed to microorganisms (i.e. bacteria and fungi) present in the soil that serve as their food source. This is somehow likely to facilitate the process of deterioration. For this reason, the soil burial test can be regarded as an authentic approach to the process of deterioration in the natural environment. The films' susceptibility to biodegradation reactions was assessed within intervals of seven days through their physical appearance and weight loss. Interestingly, it was found that the cross-linked starch films have been observed to degrade slower than the non-cross-linked starch films as burial time progressed. The declining percentages of weight loss, as well as the presence of microorganisms and eroded surface on the films observed by SEM, explained the degradation behavior of the cross-linked starch films compared to the noncross-linked starch films. Hence it is believed that cross-linked starch-glycerol films are biodegradable in soil, henceforth, the potential to be commercialized as a biodegradable packaging material soon. At the same time, this plastic packaging is expected to be recognized as a value-added product since the raw materials ergo mango seeds utilized to develop this product are from waste, therefore, environmentally friendly.
\end{abstract}

ABSTRAK: Plastik yang berasaskan petroleum telah mencetuskan masalah persekitaran. Untuk tujuan ini, polimer biodegradasi seperti kanji sering digunakan untuk membuat plastik yang boleh terurai. Pada masa ini, usaha sedang dilakukan untuk mengekstrak pati sebagai biopolimer yang menjanjikan dari biji mangga dan kemudiannya menghasilkan filem pati yang terbiodegradasi untuk digunakan sebagai kemasan plastik. Oleh yang demikian, dalam karya ini, filem pati mangga plastik-gliserol disusun menggunakan proses pemutus larutan, menggunakan jumlah asid sitrik yang berlainan sebagai agen penghubung silang. Nisbah campuran pati dan gliserol ditetapkan pada 3:5 wt.\% masingmasing, sementara jumlah asid sitrik berkisar antara 0 hingga 10 wt.\% berat. Kemudian, sampel plastik tersebut ditanam di dalam tanah selama 21 hari di persekitaran semula jadi untuk menentukan tingkah laku biodegradasinya. Ujian penguburan tanah adalah salah 
satu kaedah biasa yang dipilih untuk menilai biodegradasi polimer. Ideanya adalah bahawa, dengan menguburkan sampel di tanah untuk waktu yang tetap, sampel terdedah kepada mikroorganisma (iaitu bakteria dan jamur) yang terdapat di dalam tanah yang berfungsi sebagai sumber makanan mereka. Ini mungkin memudahkan proses kemerosotan. Atas sebab ini, ujian penguburan tanah dapat dianggap sebagai pendekatan yang sahih terhadap proses kemerosotan di persekitaran semula jadi. Kerentanan filem terhadap reaksi biodegradasi dinilai dalam selang waktu tujuh hari melalui penampilan fizikal dan penurunan berat badan. Menariknya, didapati bahawa filem-filem pati berangkai silang telah dilihat menurun lebih perlahan daripada filem-filem pati yang tidak bersilang ketika masa pengebumian berlangsung. Peratusan penurunan berat badan yang menurun, serta kehadiran mikroorganisma dan permukaan yang terhakis pada filem yang diperhatikan oleh SEM, menjelaskan tingkah laku degradasi filem pati berangkai silang berbanding dengan filem pati yang tidak bersilang. Oleh itu, dipercayai bahawa filem kanji-gliserol berangkai silang dapat terbiodegradasi di dalam tanah, dan seterusnya, potensi untuk dikomersialkan sebagai bahan pembungkusan yang boleh terurai tidak lama lagi. Pada masa yang sama, pembungkusan plastik ini diharapkan dapat diakui sebagai produk bernilai tambah kerana bahan mentah ergo mangga yang digunakan untuk mengembangkan produk ini adalah dari sisa, oleh itu, mesra alam.

\section{KEYWORDS: mango seed; starch; biodegradable polymer; soil burial}

\section{INTRODUCTION}

Over the past several years, due to the rise in environmental concerns, research has been focused on biodegradable materials in reducing the reliance on petroleum-based materials. For this purpose, a biopolymer has been widely developed as an alternative to conventional materials due to their attractive benefits such as biodegradability and sustainability towards the environment [1]. At present, the development of biodegradable materials based on polymers has been attempted in several approaches [2]. One of the approaches is to produce polymeric materials based on inherently biodegradable materials. This has been attracting rising interest in the utilization of starch as a biopolymer. Consequently, the biodegradable constituent is predicted to be degraded rapidly by environmental factors such as biological activity, chemical conditions, moisture, heat, and light, initiating an overall deterioration of the polymeric matrix, which in turn boosts the disintegration of the whole material $[2,3]$.

In this analysis, mango seeds were used to get native starch. Mango (Mangifera indica) belongs to the genus Mangifera in the Anacardiaceae family of flowering plants, is a common tropical fruit, and is widely grown practically. Throughout the world's tropical and subtropical regions like Malaysia, Thailand, and India [4]. These types of fruits are usually consumed as fresh or processed into juices, and their seeds are discarded as waste. Interestingly, these seeds are rich in starch and protein [5]. Therefore, the seeds fit as a viable source of starch. Because starch does not possess thermoplastic properties, polyols, such as glycerol, are often used as plasticizers to improve the workability and flexibility, as well as to overcome the brittleness of the native starch [6]. However, the usage of starch in developing biodegradable plastics may have several drawbacks. Its hydrophilic characteristic may cause the synthesized materials to have a high-water sensitivity, poor moisture barrier properties, and high retrogradation over some time. Hence, poly-carboxylic acids, such as citric acid, are introduced as cross-linking agents during the blending of thermoplastic starch to overcome the retrogradation phenomenon and improve its performance in numerous applications. Citric acid is known as a natural organic acid, is nutritionally harmless compared with other substances, and consists of multi-carboxylic structures [7]. 
Soil burial biodegradability behavior of starch incorporated with biopolymers such as starch grafted low-density polyethylene (LDPE) [8], corn starch with chitosan [9], and corn starch with polyvinyl alcohol $(\mathrm{PVOH})[10]$ have been demonstrated. A similar approach by crosslinking cassava starch with citric acid has been reported its biodegradability properties through soil burial [7]. From these literatures, it can be concluded that starch-based films prepared from different sources of starch exhibited biodegradable behavior. However, study related to the biodegradability behavior of mango seed starch-based films is rarely reported. Hence, in this research, the utilization of starch from mango seeds specifically obtained at the local market in Malaysia have been processed to prepare the films. The extraction processes of the mango seeds included the separation between the kernel (outer) and cotyledon (inner), in which only the inner seeds were further processed and blended with glycerol and citric acid to fabricate films. This is to differentiate the findings obtained in this work with the mango kernel starch plasticized with glycerol and sorbitol that has been reported previously [11], which does not consider the biodegradation testing. The primary objective of this research was to develop a biodegradable starch-based film for packaging materials applications via solution casting method. Prior to the main objective, a biodegradability analysis was conducted using a soil burial test to investigate the effect of cross-linking on the degradation rate of the glycerol-plasticized thermoplastic mango seed starch (GTPS) films. It is expected that the non-cross-linked and cross-linked GTPS films will experience weight loss during the soil burial test, proving that these films are biodegradable and sustain the environment after usage as packaging.

\section{MATERIALS AND METHODS}

\subsection{Raw Materials}

Mango seeds had been collected from the local market as a source of starch. $85 \%$ pure glycerol was procured from Merck Sdn. Bhd. (Selangor, Malaysia) and reagent-grade citric acid ( $\geq 99 \%$ purity) was procured from Sigma-Aldrich Sdn. Bhd. (Selangor, Malaysia).

\subsection{Extraction of Mango Seed Starch via Distillation Method}

The starch from mango seed was extracted with minor modifications according to the procedure defined by Noor et al. [5]. Initially, $5 \mathrm{~g}$ of mango seed flour was introduced to $100 \mathrm{ml}$ of distilled water at room temperature, with continuous stirring for $6 \mathrm{~h}$. Then, the slurry was filtered with a cloth bag (about $200 \mu \mathrm{m}$ mesh), and the excess residues were rinsed three times with distilled water. The filtrate was immersed and precipitated at $4{ }^{\circ} \mathrm{C}$ overnight. Finally, the starch obtained was filtered and dried in the oven for $24 \mathrm{~h}$ at $40{ }^{\circ} \mathrm{C}$. The starch was crushed with a mortar and pestle, wrapped in a sealed plastic bag, and held at room temperature for further use.

\subsection{Preparation of Starch-Glycerol Film Cross-linked with Citric Acid}

Starch-glycerol films that were cross-linked with citric acid were processed with some modifications using the solution casting method recommended by Seligra et al. [7] and Reddy \& Yang [8]. The starch-to-glycerol ratio was set at 3:5 (wt.\%), while the citric acid content ranged from $0 \mathrm{wt} . \%$ to $10 \mathrm{wt} \%$. The total input mass was kept at $100 \mathrm{~g}$. Abbreviations of the material and corresponding sample compositions are presented in Table 1. The blends were heated to $90{ }^{\circ} \mathrm{C}$ on a hot plate and kept with continuous stirring at $250 \mathrm{rpm}$ during this temperature for $20 \mathrm{~min}$. The formulations then were cooled to $65^{\circ} \mathrm{C}$ and poured on an acrylic sheet. The cast films were allowed to dry in an oven at $40{ }^{\circ} \mathrm{C}$ and then peeled off plates after around 24 hours. The peeled films were preserved at $23{ }^{\circ} \mathrm{C}$ and $30 \%$ relative humidity in a desiccator before characterization. 
Table 1: Abbreviations and corresponding compositions of each sample

\begin{tabular}{lccccc}
\hline \multirow{2}{*}{ Material } & \multirow{2}{*}{ Abbreviation } & \multicolumn{4}{c}{ Weight Proportion (g) } \\
\cline { 3 - 6 } & & Starch & Glycerol & Citric Acid & Distilled Water \\
\hline GTPS-CA0 & G5 & 3.0 & 0.5 & 0 & 96.5 \\
GTPS-CA1 & CA2 & 3.0 & 0.5 & 0.2 & 96.3 \\
GTPS-CA2 & CA4 & 3.0 & 0.5 & 0.4 & 96.1 \\
GTPS-CA3 & CA6 & 3.0 & 0.5 & 0.6 & 95.9 \\
GTPS-CA4 & CA8 & 3.0 & 0.5 & 0.8 & 95.7 \\
GTPS-CA5 & CA10 & 3.0 & 0.5 & 1.0 & 95.5 \\
\hline
\end{tabular}

\subsection{Fourier-Transformed Infrared (FT-IR) Spectroscopy}

FT-IR spectroscopy was used to examine the functional properties of non-cross-linked and cross-linked GTPS films (Spectrum 100, Perkin Elmer; USA). FT-IR spectra were recorded using an attenuated total reflection (ATR) method to study the functional groups in starch. The analysis was performed in the $4000 \mathrm{~cm}^{-1}-600 \mathrm{~cm}^{-1}$ range, with a resolution of $8 \mathrm{~cm}^{-1}$ and a scanning frequency of 32 per sample.

\subsection{Soil Burial Degradation}

Degradation behavior of starch-based film incorporated with 5 wt.\% glycerol crosslinked with $0,2,4,6,8$, and 10 wt. $\%$ citric acids was carried out by soil burial test using procedures mentioned by Azahari et al. [9] with slight modification. The soil will cover a grid from all the sides of the grid by cutting three samples of each film measuring between $20 \mathrm{~mm}$ and $20 \mathrm{~mm}$. Samples of every composition were then buried in separate pots of composted soil at a depth of $50 \mathrm{~mm}$. The soil was then exposed to the natural weather and positioned in the open area.

The weight loss of all samples was calculated at regular intervals of time ( 7 days) for the degradation rate of samples. The samples were carefully separated from the soil and washed away soil from the film with distilled water. The sample was left to dry, and the electronic mass balance was used to measure the weight of the dried sample. During the soil burial test, the weight loss of the sample was assessed according to Eq. (1):

$$
\text { Weight loss }(\%)=\frac{W_{i}-W_{d}}{W_{i}} \times 100
$$

where $\mathrm{W}_{\mathrm{i}}$ is the sample's initial weight $(\mathrm{g})$ and $\mathrm{W}_{\mathrm{d}}$ is the sample's weight $(\mathrm{g})$ after seven days.

\subsection{Scanning Electron Microscopy (SEM) Test}

The morphology of the film surfaces before and after the soil burial test were examined using a scanning electron microscope (JEOL, JSM-IT 100; Japan), operated at an acceleration voltage of $7 \mathrm{kV}$. The samples were sputter-coated with palladium (SC7620 Sputter Coater, Quorum Technologies Ltd, Lewes, United Kingdom).

\section{RESULTS AND DISCUSSION}

\subsection{Functional Properties}

Figure 1 shows the FT-IR spectra of cross-linked mango seed starch-glycerol films. The observed peaks are the functional groups of starch, glycerol, and citric acid, with minor variations in intensity and band position. The following characteristic bands were visible in all spectra: $3270-3315 \mathrm{~cm}^{-1}$ corresponds to the stretching of the $\mathrm{O}-\mathrm{H}$ group of starch, 
glycerol, and water, $2924-2928 \mathrm{~cm}^{-1}$ corresponds to the stretching of the C-H group due to the formation of intermolecular and intramolecular bonds between starch and glycerol hydroxyl groups, and $1611-1633 \mathrm{~cm}^{-1}$ corresponds to water related absorbance.

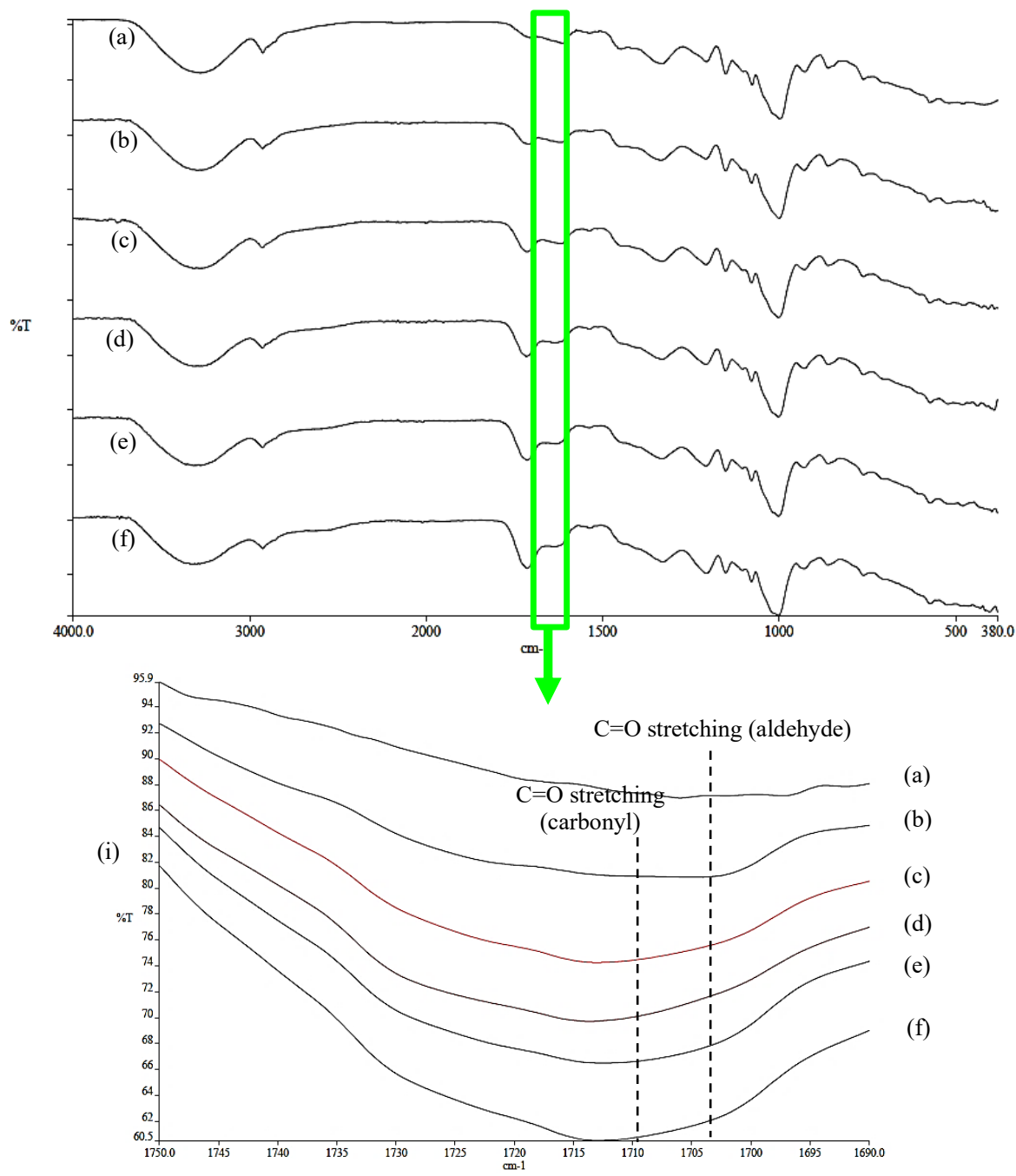

Fig. 1: FT-IR spectra of mango seed starch-glycerol cross-linked with citric acid concentrations of (a) 0, (b) 2 , (c) 4, (d) 6, (e) 8, and (f) $10 \mathrm{wt} . \%$.

The addition of citric acid to the blend causes changes in the peaks. The hydroxyl grouprelated peak at $3270-3315 \mathrm{~cm}^{-1}$ was wider and less intense. This meant that there were more $\mathrm{O}-\mathrm{H}$ in the blend that could easily vibrate, resulting in more $\mathrm{O}-\mathrm{H}$ forming hydrogen bonds [7]. Furthermore, the addition of citric acid to the GTPS resulted in peaks shifting from $998.30 \mathrm{~cm}^{-1}$ to $1000.23 \mathrm{~cm}^{-1}$. This demonstrates that the interactions of citric acid's hydroxyl and carboxyl groups with $\mathrm{C}-\mathrm{O}$ groups of C-O-C in starch are weaker than those of glycerol [6]. It is also observed that both non-cross-linked (Fig. 1(a)) and cross-linked films (Fig. 1(b) - 1(f)) have similar peaks, except for the additional peak in the cross-linked film at $1712-1713 \mathrm{~cm}^{-1}$. The $\mathrm{C}=\mathrm{O}$ peak was attributed to the carboxyl and ester carbonyl bands, where there was chemical linkage from acid groups esters between citric acid and glycerol, as well as esters between starch and citric acid [7,12]. This suggests that crosslinking occurred in the starch-glycerol films. The addition of citric acid resulted in more intense peaks, implying that citric acid is more capable of disrupting starch chains' intermolecular and intramolecular hydrogen bonds $[13,14]$. 


\subsection{Visual Observation}

The pictorial view of the samples retrieved after being subjected to natural soil burial test for 21 days is presented in Fig. 2. This denoted that the visual changes of samples can be used as the first indication of any surface degradation.

From the figure, it was observed that the non-cross-linked films and cross-linked films at $2 \mathrm{wt} . \%$ to $10 \mathrm{wt} . \%$ citric acid contents started to experience deterioration in the first seven days. The deterioration of starch-based films in soil was governed by hydrolytic degradation, in which the excess water permeated through the soil and diffused into the samples, causing films to become soft and swelled. This could be described by the appearance of samples that seemed fragile and brittle and diminished in size. Specifically, after being buried 21 days in soil, GTPS-CA0 showed major deterioration compared to GTPS-CA2. Increasing citric acid content from $2 \mathrm{wt} . \%$ to $10 \mathrm{wt} . \%$, making the cross-linked films more resistant to deterioration. At the same time, it was also noticed that there are white particles spotted on films, which are believed as micro-organisms on the surface of all samples. By some means, the deterioration of samples was boosted by the microbial attack, evidenced by SEM images (Fig. 3). Moreover, the macro-organisms like fungus gnat larvae, the worm-like creatures that squirm their way around in soil and fungi to feed the decaying samples, hence boost up the degradation rate. These results imply that the films were degraded and decomposed in the soil environment, although the degradation rates were significantly varied among the starch-based films.

\begin{tabular}{|c|c|c|c|c|c|c|}
\hline Sample / Day & GTPS-CA0 & GTPS-CA2 & GTPS-CA4 & GTPS-CA6 & GTPS-CA8 & GTPS-CA10 \\
\hline 0 day & & & & & & \\
\hline 7 days & & & & & 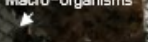 & \\
\hline 14 days & & & & & & \\
\hline 21 days & & & & & & \\
\hline
\end{tabular}

Fig. 2: Macroscopic appearance of non-cross-linked and cross-linked mango seed starchglycerol films after being buried for 21 days.

\subsection{Morphological Properties}

SEM micrographs are shown in Fig. 3(a) - 3(f) visualized the morphological changes of mango seed starch-glycerol-citric acid films after being subjected to a soil burial test for 7 days. The observation was done in short-term degradation due to the unfeasibility in observing the morphology of films after 21 days since there were only tiny pieces of films left when retrieved from the soil, shown previously. 
The morphology of starch-glycerol films with 0 wt.\% citric acids displayed a significantly eroded surface with plentiful filamentous fungus, fungus colonization, and pores (Fig. 3(a)). The addition of citric acid from $2 \mathrm{wt} . \%$ to $10 \mathrm{wt} . \%$ in starch and glycerol blend (Fig. 3(b) - 3(f)) revealed the surface of the samples were colonized by microorganisms, however, with the existence of less filamentous fungus, fungus colonization, puffball spores, and pores. Thus, it seems that starch-glycerol films with higher citric acid content degrade slowly, consequently had a lower percentage of weight loss (Section 3.4).

During the exposure of samples in soil within 7 days, the formation of numerous pores and microbial biofilm with many cells growing on the starch-based films appeared. The presence of pores on the deteriorated samples upon the biodegradation process is associated with the starch consumption by the microorganisms, lead to enhancement of microorganisms, water, and oxygen accessibility into the polymer matrix, and caused weight loss of samples. At the same time, the exposed films' surface facilitates moisture permeation that fosters microbial attack on the starch and hydrolysis of the matrix component [15]. Furthermore, the deterioration of starch-based films was also contributed by the fungal strains [16]. It is noted that the fungal species that existed in the film was identified as Aspergillus sp. It is noticed in the form of the filamentous and unicellular arrangement was reproduced by spores. These micro-organisms are believed to exploit the starch film as a sole carbon source, causing degradation of films in the soil condition. A similar type of micro-organisms associated with polymer degradation in the soil was reported earlier [16] on cassava starch-based films. Besides, the existence of filamentous fungus, spores, and fungus colonization on the film surface concurs with the fact that fungi are pervasive and very effective in influencing the film's biodegradability behavior, especially in the soil condition. The observation is per the findings reported previously [17].
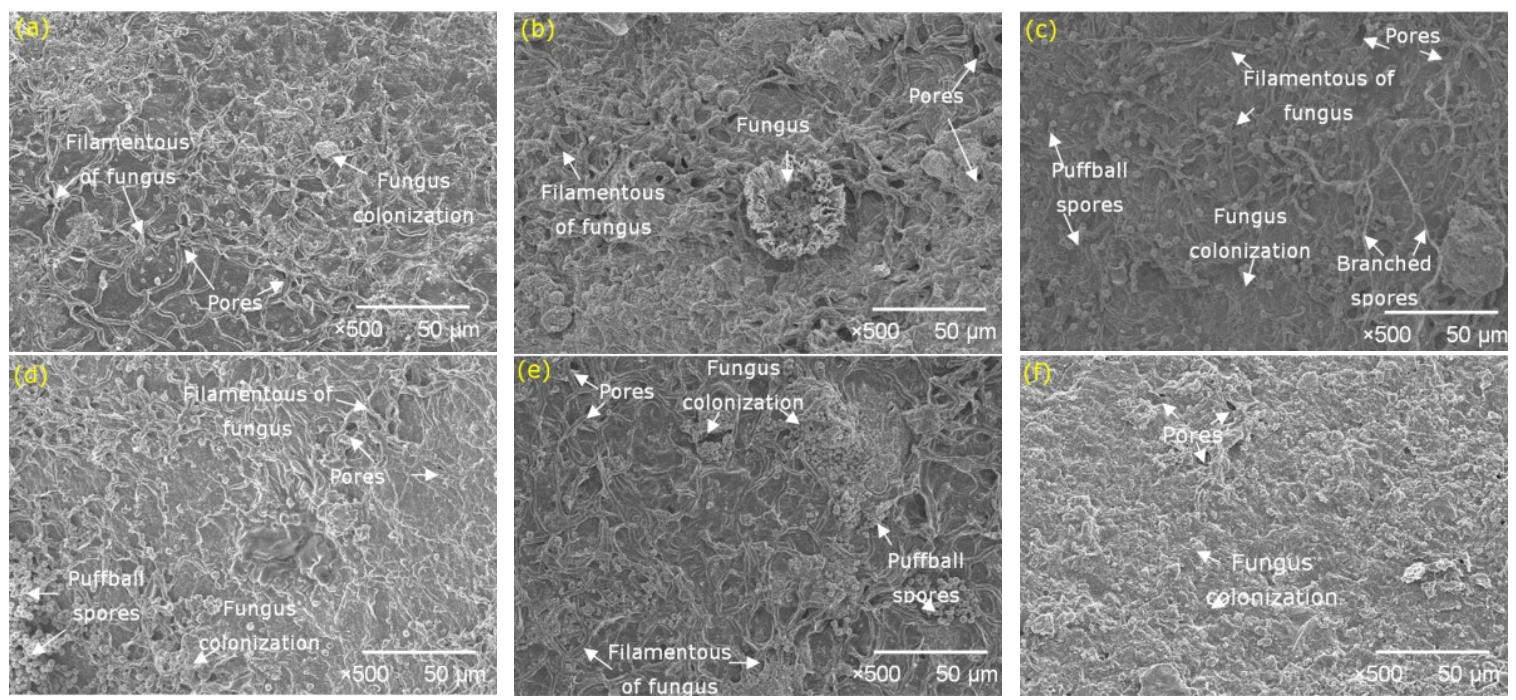

Fig. 3: SEM micrographs at 500× magnification of cross-linked mango seed starch films with various citric acid concentrations (a) 0, (b) 2, (c) 4, (d) 6, (e) 8, and (f) $10 \mathrm{wt} . \%$.

\subsection{Weight Loss}

The percent weight loss of mango seed starch-glycerol films cross-linked with different amounts of citric acid after being buried in soil for 21 days is illustrated in Fig. 4. It was noticed that the percent weight loss of all samples progressed continuously over time.

The result revealed that the non-cross-linked films (GTPS-CA0) achieving the highest weight loss, thus denote the fastest rate of degradation compared to cross-linked films. The addition of citric acid to starch and glycerol blend resulted in a low percentage of weight 
loss. It was also remarked that the maximum weight losses were $91.76 \%, 91.41 \%, 90.32 \%$, $87.93 \%, 86.44 \%$, and $85.94 \%$ for GTPS-CA0, GTPS-CA2, GTPS-CA4, GTPS-CA6, GTPS-CA8, and GTPS-CA10, respectively after 21 days of soil burial.

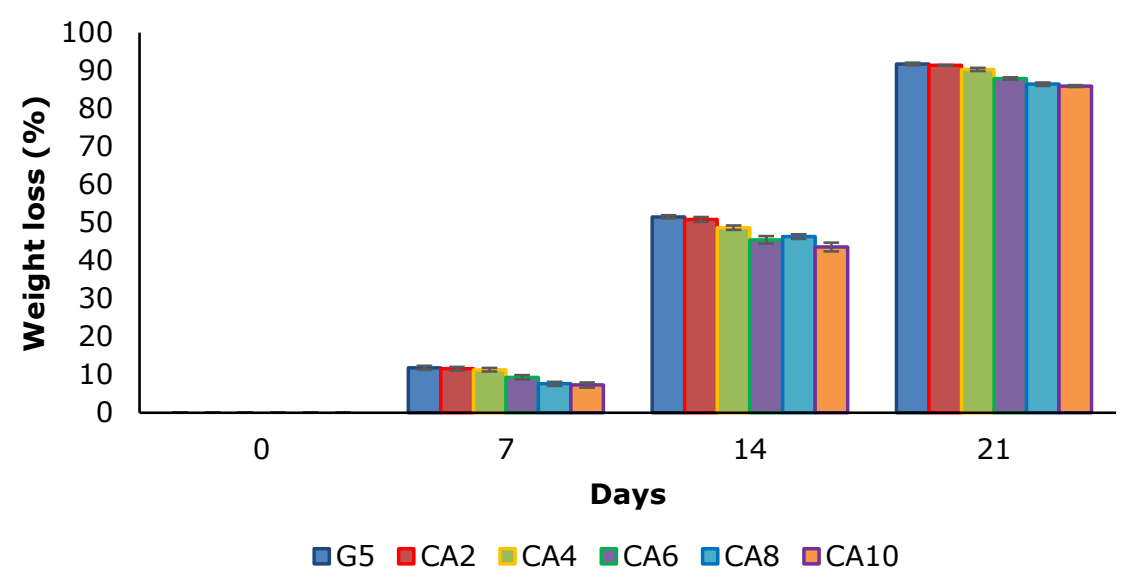

Fig. 4: Weight loss of non-cross-linked and cross-linked mango seed starch-glycerol films after buried in soil for 21 days.

Based on Fig. 4, it was found that the weight loss observed after 21 days of soil burial was decreased with increasing citric acid content. Within the burial time, the starch-glycerol films might absorb adequate water because of their hydrophilic characteristics, which facilitates microbial attack and hydrolysis of the matrix component. As a result, the hydrolytic depolymerization of starch chains to monomeric units occurs, and the probable deterioration of films is caused by microorganisms [18]. Eventually, the formation of pores on the film surfaces as being viewed in SEM micrographs (Fig. 3) indicates the starch consumption by microorganisms. It is also important to note that the starch also might be attacked by micro-organisms as being visually observed (Fig. 2), which might feed on the starch as a source of food, henceforth deteriorate the films. Increasing citric acid content in starch and glycerol blend leads to a slower degradation rate because lesser microorganisms invade the films and weaker interaction of hydrogen bonds within the starch chains.

However, the weight losses may underestimate because the soil and debris have adhered to the film surface. The weight loss of the cross-linked starch-glycerol films at 21 days of soil burial proved that they are biodegradable. This is in agreement with the findings reported [7] in cassava starch-glycerol cross-linked with citric acid, who observed that cross-linked films degrade slower in soil than non-cross-linked films.

\section{CONCLUSION}

From the present study, it is confirmed that the cross-linked mango seed starch-glycerol films are proved by the FT-IR spectra and its biodegradability by soil burial tests. The results obtained from the visual observation after exposure to soil burial test revealed that crosslinked starch films degrade slower which has been justified by the decreasing weight loss percentages as well as the presence of microorganisms and eroded surface on the films detected by SEM. It is therefore hoped that the fabrication of mango seed starch-based films as biodegradable plastic packaging would soon minimize the environmental pollution mainly caused by typical petroleum-based plastics, specifically single-use plastics. Having said that, the use of mango seeds as raw materials to produce biodegradable plastics will also offer a value-added material and reduce the production cost. Overall, the extent of 
starch-based film degradation following exposure to soil burial has been extensively inferred in this work.

\section{ACKNOWLEDGEMENT}

The authors wish to thank the International Islamic University Malaysia for the financial support (Research Initiative Grant - RIGS16-072-0236 and Fundamental Research Grant Scheme - FRGS17-033-599).

\section{REFERENCES}

[1] Lu DR, Xiao CM, Xu SJ. (2009). Starch-based completely biodegradable polymer materials, 3(6):366-375. https://doi.org/10.3144/expresspolymlett.2009.46

[2] Sutivisedsak N, Cheng HN, Dowd MK, Selling GW, Biswas A. (2012) Evaluation of cotton byproducts as fillers for poly (lactic acid) and low-density polyethylene. Industrial Crops and Products, 36(1):127-134. https://doi.org/10.1016/j.indcrop.2011.08.016

[3] Orhan Y, Hrenović J, Büyükgüngör H. (2004) Biodegradation of plastic compost bags under controlled soil conditions. Acta Chimica Slovenica, 51(3): 579-588.

[4] Hassan LG, Muhammad AB, Aliyu RU, Idris ZM, Izuagie T, Umar KJ, Sani NA. (2013) Extraction and Characterisation of Starches from Four Varieties of Mangifera indica Seeds. IOSR Journal of Applied Chemistry, 3(6):16-23.

[5] Noor F, Rahman J, Mahomud S, Akter MS, Talukder AI, Ahmed M. (2014) Physicochemical properties of flour and extraction of starch from jackfruit seed. International Journal of Nutrition and Food Sciences, 3(4): 347-354. https://doi.org/10.11648/j.jinfs.20140304.27

[6] Jiugao Y, Ning W, Xiaofei M. (2005) The effects of citric acid on the properties of thermoplastic starch plasticized by glycerol. Starch/ Staerke, 57(10):494-504. https://doi.org/10.1002/star.200500423

[7] Seligra PG, Jaramillo CM, Fama L, Goyanes S. (2016) Biodegradable and non-retrogradable eco-films based on starch-glycerol with citric acid as cross-linking agent. Carbohydrate Polymers, 138:66-74. https://doi.org/10.1016/j.carbpol.2015.11.041

[8] Gautam N, Kaur I. (2013) Soil burial biodegradation studies of starch grafted polyethylene and identification of Rhizobium meliloti therefrom. Journal of Environmental Chemistry and Ecotoxicology, 5(6):147-158. https://doi.org/10.5897/JECE09.022

[9] Coniwanti P, Laila L, Alfira MR (2014). Pembuatan Film Plastik Biodegredabel Dari Pati Jagung Dengan Penambahan Kitosan Dan Pemplastis Gliserol. Jurnal Teknik Kimia, 20(4):2230.

[10] Azahari NA, Othman N, Ismail H. (2011) Biodegradation Studies of Polyvinyl Alcohol / Corn Starch Blend Films in Solid and Solution Media, 22(2):15-31.

[11] Nawab A, Alam F, Haq MA, Hasnain A. (2016) Biodegradable film from mango kernel starch: Effect of plasticizers on physical, barrier, and mechanical properties. Starch - Stärke, 68 (9 10):919-928. https://doi.org/10.1002/star.201500349

[12] Reddy N, Yang Y. (2010) Citric acid cross-linking of starch films. Food Chemistry, 118(3):702-711. https://doi.org/10.1016/j.foodchem.2009.05.050

[13] Shi R, Zhang Z, Liu Q, Han Y, Zhang L, Chen D, Tian W. (2007) Characterization of citric acid/glycerol co-plasticized thermoplastic starch prepared by melt blending. Carbohydrate Polymers, 69(4):748-755. https://doi.org/10.1016/j.carbpol.2007.02.010

[14] Zuraida A, Anuar H, Yusof Y. (2011) The Study of Biodegradable Thermoplastics Sago Starch. Key Engineering Materials, 471-472:397-402. https://doi.org/10.4028/www.scientific.net/kem.471-472.397

[15] Sarifuddin N, Ismail H, Ahmad Z. (2014) Incorporation of Kenaf Core Fibers into Low-Density Polyethylene/Thermoplastic Sago Starch Blends Exposed to Natural Weathering. Molecular Crystals and Liquid Crystals, 603(1):180-193. https://doi.org/10.1080/15421406.2014.976516 
[16] Maran JP, Sivakumar V, Thirugnanasambandham K, Sridhar R. (2014) Degradation behavior of biocomposites based on cassava starch buried under indoor soil conditions. Carbohydrate Polymers, 101(1):20-28. https://doi.org/10.1016/j.carbpol.2013.08.080

[17] Nuradibah MA, Sam ST, Noriman NZ, Ragunathan S, Ismail H. (2015) Degradation assessment of natural weathering on low-density polyethylene/thermoplastic soya spent powder blends. AIP Conference Proceedings, 1669:020040. https://doi.org/10.1063/1.4919178

[18] Obasi HC, Igwe IO, Madufor IC. (2013) Effect of Soil Burial on Tensile Properties of Polypropylene / Plasticized Cassava Starch Blends. Advances in Materials Science and Engineering, 2013:2-5. 